\title{
Reduction of nutrient losses with eroded sediments by post-fire soil stabilisation techniques
}

\author{
M. X. Comez-Rey , A. Couto-Vazquez, S. Carcfa-Marco , J. A. \\ Vega and S. J. Gonzalez-Prieto
}

\begin{abstract}
After an experimental fire in steep shrubland in a temperate-humid region (north-west Spain), the effects of two post-fire stabilisation treatments (grass seeding and straw mulching) on the chemical properties of eroded sediments, and the amount of nutrients lost with them, were evaluated relative to control burnt soil, over a period of 13 months. Total C and $\mathrm{N}$ concentrations, and $8{ }^{13} \mathrm{C}$, indicated that sediments were mainly contributed by charred plant and litter material. The highest concentrations of extractable base cations in the sediments occurred during the first 3 months following fire, especially for $\mathrm{Na}$ and $\mathrm{K}$. As treatments had little or no effect on nutrient concentration in sediments, differences in nutrient losses were due to the 10-fold lower sediment production in mulching compared with other treatments. In control and seeding treatments, the accumulated amounts of nutrients lost with sediments were 989-1028 kg ha"1 (C), $77 \mathrm{~kg} \mathrm{ha"1}^{1}$ (N), 1.9-2.4 kg ha"1 (Ca),

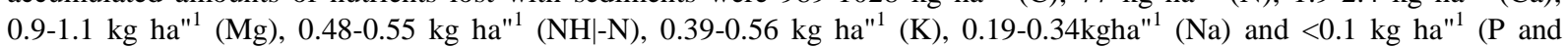
NOF-N). These values accounted for 22-25\% (total C and N) and 5-12\% (NH|-N, Ca, P and Mg) of available nutrients in ash, and $1.0-2.4 \%$ of those in ash+topsoil. As nutrient and sediment losses were strongly correlated, the reduction of the latter by mulching application leads to an effective decrease of post-fire nutrient losses.
\end{abstract}

\section{Introduction}

Wildfires destroy the vegetation cover and can greatly accelerate the processes of soil degradation (physical, chemical and biological) and nutrient losses through volatilisation, leaching and erosion (Certini 2005). Soil erosion rates typically increase after a wildfire due to reduced ground cover (Diaz-Fierros et al. 1987; Robichaud and Brown 1999) and changes in soil physical characteristics (Martin and Moody 2001; Cerda and Lasanta 2005). After fire, the highly available nutrients accumulated in the ash and the upper soil layer are vulnerable to losses by leaching, wind and runoff (DeBano et al. 1998). Despite universal recognition of erosion as a prevalent post-fire process, most studies have focussed on nutrient losses in solution, with less emphasis on the importance of nutrients attached to sediments and, therefore, little is known concerning nutrient losses associated with the eroded material (de Koff et al. 2006). Shortly after a fire, compared with soil surface, debris leaving a burnt area is enriched in organic matter, $\mathrm{P}$, mineral $\mathrm{N}$ and exchangeable cations (Carreira and Niell 1995; Andreu et al. 1996; Thomas et al. 1999) and, consequently, nutrient losses with sediments can substantially exceed those lost in solution (Debano and Conrad 1978; Gimeno-Garcia et al. 2000;
Smith et al. 2011). The increase in nutrients in eroded sediments has been related to fire intensity (Andreu et al. 1996; Gimeno-Garcia et al. 2000), but it was also observed after low intensity prescribed fires (de Koff et al. 2006).

Although post-fire erosion effects on downstream water quality and sedimentation (Smith et al. 2011) are recognised, several authors consider that nutrient losses in eroded sediments are unlikely to affect long-term site productivity (Helvey et al. 1985; Emmerich 1999; Robichaud et al. 2006) taking into account the small amounts of nutrients in sediments compared with those lost from burning, or accumulated in soils and the post-fire ash-layer (Grier 1975; Feller 1988; Means et al. 1992; Busse 1994; Baird et al. 1999). By contrast, other authors consider that soil quality might well be seriously affected through preferential loss of fines and organic matter, both of which contain more nutrients than does the remainder of the soil (Thomas et al. 1999; Shakesby et al. 2002). Moreover, the fate of eroded C (e.g. sequestration or oxidation) could affect the global $\mathrm{C}$ budget, and $\mathrm{N}$ and P delivery to waterbodies can lead to eutrophication (Gabet et al. 2005).

Post-fire erosion rates are highly variable (reported values range from 1 to $240 \mathrm{Mg}$ ha" ; Robichaud et al. 2006; Moody and 
Martin 2009) and are strongly related to the percentage of bare soil (Vega et al. 2005); they generally decrease by an order of magnitude with each year of recovery (Robichaud et al. 2000, 2006), leading to the greatest nutrient losses in the first 4-12 months after fire (Gimeno-Garcia et al. 2000; de Koff et al. 2006; Robichaud et al. 2006). Therefore, post-fire soil stabilisation techniques (e.g. seeding and mulching) must be applied as soon as possible to accelerate development of ground and vegetation cover, reduce surface runoff and prevent soil erosion (Pinaya et al. 2000; Robichaud et al. 2000; Vega et al. 2005; Wagenbrenner et al. 2006; Robichaud 2009; Fernandez et al. 2011, 2012). In many countries, seeding of fast-growing non-native grass species is the most common post-fire stabilisation technique to rapidly increase plant cover because of its relatively low cost and easy aircraft application (Robichaud et al. 2000; Beyers 2004). However, this practice has been questioned because it can introduce exotic species (Kruse et al. 2004) and displace native species, interfering with natural vegetation recovery (Beyers 2004). Furthermore, grass seeding could be ineffective in increasing ground cover or reducing erosion rates during the first critical rain events after a fire (Robichaud et al. 2006; Wagenbrenner et al. 2006; Groen and Woods 2008; Peppin et al. 2010; Fernandez et al. 2012). As an alternative, straw mulch is increasingly being applied to burnt areas with high value due to its immediate effectiveness in increasing ground cover and erosion control (Bautista et al. 2009; Robichaud et al. 2010). Previous studies have shown that mulching can reduce sediment production by $30-94 \%$ during the first critical months following fire (Wagenbrenner et al. 2006; Groen and Woods 2008; Fernandez et al. 2011; Diaz-Ravifia et al. 2012).

Despite its great importance, few studies have focussed on the effects of fire on soil nutrients removed in eroded soil material (DeBano et al. 1998; Gabet et al. 2005; Robichaud et al. 2006; Spigel and Robichaud 2007) and even fewer have dealt with the effectiveness of post-fire stabilisation techniques to reduce nutrient losses by erosion (Thomas et al. 2000; Robichaud et al. 2006). In this context, the aim of the present study was to evaluate, over a period of 13 months, the effects of two post-fire stabilisation techniques (seeding and mulching) on nutrient losses ((total carbon (C) and nitrogen (N), ammonium (NH4"), nitrate (NO3"), sodium $(\mathrm{Na})$, potassium $(\mathrm{K})$, magnesium $(\mathrm{Mg})$, calcium (Ca) and phosphorous (P)) with the eroded sediments following an experimental fire in a shrubland ecosystem from the temperate-humid region of north-west Spain, an area with one of the highest fire incidence in Europe (Birot 2009). A complementary objective was to monitor the evolution of $\mathrm{pH}$ and the natural abundance of ${ }^{13} \mathrm{C}$ and ${ }^{15} \mathrm{~N}$ in the eroded sediments.

\section{Material and methods}

\section{Site description and experimental design}

The experimental site was located in the Monte Cabalar (42³8'58"N; 8²9'31"W, 660 m above sea level) at A Estrada (Galicia, north-west Spain). The area has a temperate climate with $3036 \mathrm{~mm}$ of accumulated precipitation during the study (October 2009-December 2010). The soil, developed over granite, is acidic with sandy loam texture and relatively high organic matter content. Vegetation cover is dominated by gorse Ulex europaeus, with some Pteridium aquilinum, $U$. gallii, Daboecia cantabrica and Pseudoarrenhaterum longifolium, with an average height of $123 \mathrm{~cm}$ and $100 \%$ of ground cover.

Before the experimental fire, there were no significant differences among plots assigned to the different treatments for any of the main characteristics, showing an acceptable spatial homogeneity of the study area for slope (38-54\%), orientation (345-359 $\left.{ }^{\circ} \mathrm{N}-\mathrm{NW}\right)$, vegetation cover (Vega et al. 2010), fuel loading (shrub stratum: $3.1 \pm 0.19 \mathrm{kgm} \sim$; litter layer: $1.7 \pm 0.26 \mathrm{~kg}$ $\mathrm{m}^{-2}$; Fonturbel et al. 2012) and soil characteristics: $\mathrm{pH}_{\mathrm{KC} 1}(3.5$ $\pm 0.1)$, total $\mathrm{N}\left(14.0 \pm 0.9 \mathrm{gkg}^{11}\right), 8^{15} \mathrm{~N}(2.4 \pm 0.5 \% \mathrm{o}), \mathrm{NHj}-\mathrm{N}$ $\left(29 \pm 15 \mathrm{mgkg}^{\wedge}{ }^{1}\right), \mathrm{NO}^{\wedge}-\mathrm{N}\left(64 \pm\right.$ ISmgkg- $\left.^{1}\right)$, total C (millgkg- $\left.{ }^{1}\right)$, $8^{13} \mathrm{C}(-27.0 \pm 0.1 \% \mathrm{o}), \mathrm{Na}\left(61 \pm 7 \mathrm{mgkg}^{1}\right), \mathrm{K}\left(132 \pm 25 \mathrm{mgkg}^{1}\right), \mathrm{Mg}$ (39 $\left.\pm 7 \mathrm{mgkg}^{1}\right)$, Ca $\left(45 \pm{ }^{\wedge} \mathrm{mgkg}^{11}\right)$ and P $\left(14 \pm 2 m g k g \wedge^{1}\right)$. Twelve experimental plots (30 x $10 \mathrm{~m}$ each), with the longest dimension parallel to the maximum slope, were established within a total area of 1.73 ha. During June 2009, the shrub was cut and laid down directly on the ground, to facilitate litter and duff combustion, and 3 months later (14 and 15 October) the plots were burnt with the backfire technique to favour soil organic cover consumption and soil heating. The rate of fire spread was slow (0.30-0.33 $\left.\mathrm{mmin}^{-1}\right)$ and the soil temperature (monitored with 10 type $\mathrm{K}$ thermocouples per plot), reached $153^{\circ} \mathrm{C}$ below the mineral soil surface and $34^{\circ} \mathrm{C}$ at 2 -cm soil depth.

To monitor post-fire erosion, the plots were delimited by a geotextile fabric similar to that described by Robichaud and Brown (2002), fixed to posts. Sediment fences made of this same fabric were established at the downhill side of each plot for periodic collection of sediments. After the experimental fire, three soil treatments were arranged in a fully randomised design with four replications: (a) burnt soil (BS), considered as control treatment; (b) mulching (M), burnt soil with $230 \mathrm{~g} v r T$ of straw mulch, which ensured a soil cover —60\%; (c) seeding (S), burnt soil with a mixture of seeds at a rate of 45gm (Lolium multiflorum, 35\%; Trifolium repens, 25\%; Dactylis glomerata, 20\%; Festuca arundinacea, 10\%; F. rubra, 5\%; Agrostis tenuis, $5 \%$ ). The soil stabilisation treatments were applied on 6 November 2009 manually in order to minimise soil perturbation.

\section{Sampling and chemical analysis of soil, ashes and sediments}

Immediately after the experimental fire, but before the application of soil stabilisation treatments, 'ash samples' (ashes+ charred plant and litter debris) were taken in 10 squares $(15 \times 15 \mathrm{~cm})$ uniformly distributed inside each plot and combined to obtain a composite sample. The same was done for topsoils (0-5-cm depth) that were sampled after removing the plant litter in the case of soils before the experimental fire (US) or the ash layer of burnt soils (BS). The field-moist soil was sieved $(<2 \mathrm{~mm})$, homogenised and stored at $4^{\circ} \mathrm{C}$ for inorganic $\mathrm{N}$ determination. Sub-samples were air-dried for chemical analyses.

After each sediment-producing rain event, eroded sediments were collected and transported to the laboratory, where they were dried and weighed (see Fig. 1). A sub-sample was taken for chemical analysis. 


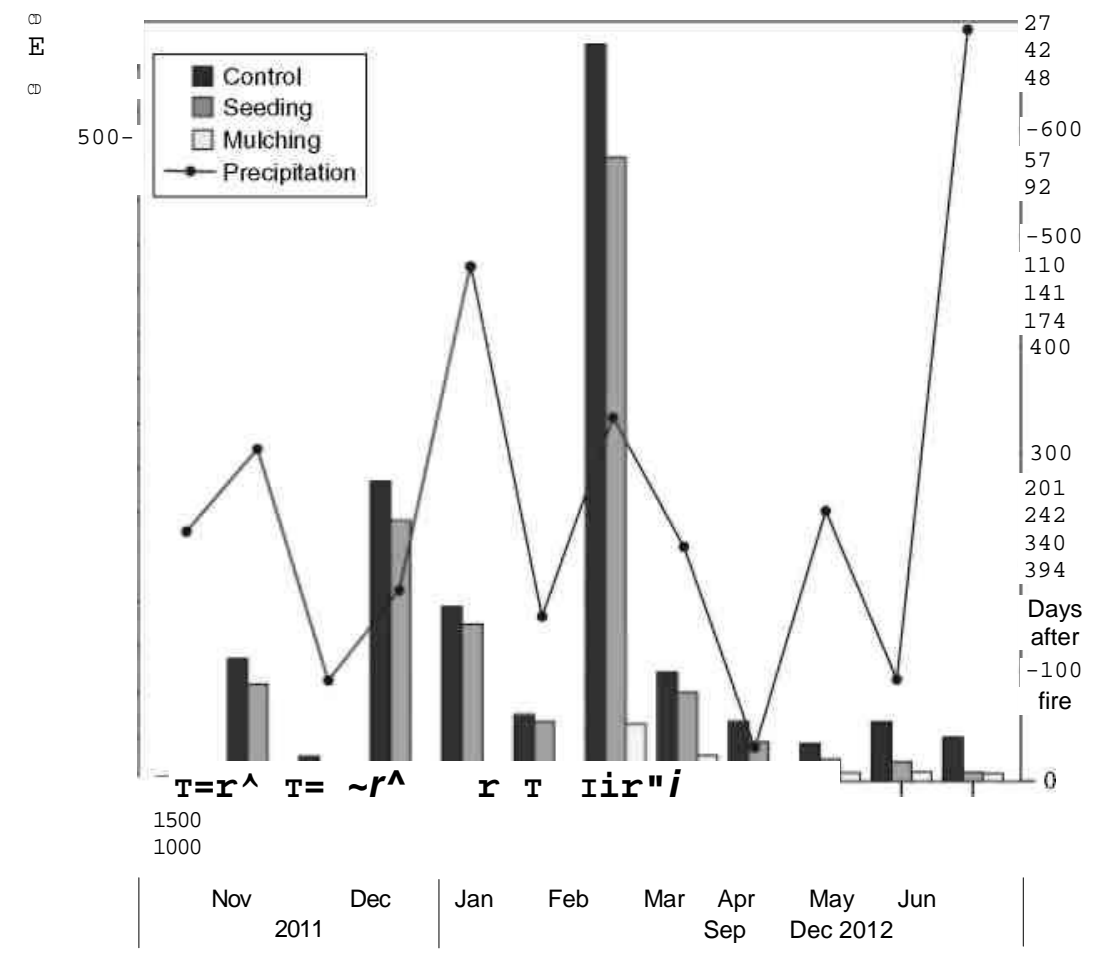

Fig. 1. Amount of sediments ( $\left.\mathrm{kg} \mathrm{ha}^{-}\right)$eroded during the first 13 months after the experimental fire in the control, seeding and mulching treatments and precipitation $(\mathrm{mm})$ during each sediment-producing rain event.

The $\mathrm{pH}$ was measured with a $\mathrm{pH}$ meter (Metrohm, Switzerland) in $\mathrm{H}_{2} 0$ and $\mathrm{KC} 1$ employing a soil: solution ratio of 1:2.5 and a sediment or ash: solution ratio of 1 : 6 . Total $\mathrm{C}$, total $\mathrm{N}, 8^{13} \mathrm{C}$ and $8^{15} \mathrm{~N}$ were measured on finely ground soil, sediments and ash samples (< 100 urn) with an elemental analyser (Carlo Erba CNS 1508, Milan, Italy) coupled online with an isotopic ratio mass spectrometer (Finnigan Mat, delta C, Bremen, Germany). Inorganic $\mathrm{N}$ was extracted by shaking $5 \mathrm{~g}$ (ash) or $20 \mathrm{~g}$ (soil or sediment) of sample for $1 \mathrm{~h}$ with 2 M KC1 (1:10 ash: solution ratio; 1: 5 soils or sediments: solution ratio). Extracts were passed through glass microfibre filters (Whatman GF/A, 125-mm diameter) and $\mathrm{NO}^{\wedge}-\mathrm{N}$ and NEEf-N were analysed by a modified diffusion method (Khan et al. 1997). In order to sequentially liberate $\mathrm{NH} \mid-\mathrm{N}$ and $\mathrm{NO} 2+\mathrm{NO}^{\wedge}-\mathrm{N}$ in the form of $\mathrm{NH}_{3}, 20-\mathrm{mL}$ aliquots of extracts, placed in a $500-\mathrm{mL}$ wide-mouth glass jar, were treated successively (24-h periods at $\left.50^{\circ} \mathrm{C}\right)$ with $\mathrm{MgO}(0.1$ g) and MgO (0.1 g) plus Devarda's alloy (0.4 g). Gaseous $\mathrm{NH}_{3}$ was trapped into $1 \mathrm{OmL}$ of $4 \mathrm{mM} \mathrm{H}_{2} \mathrm{SO}_{4}$ in a Teflon bottle attached to the glass jar and measured by back titration of the excess of $\mathrm{H}_{2} \mathrm{SO}_{4}$ with $0.004 \mathrm{M} \mathrm{NaOH}$. For extractable $\mathrm{Na}, \mathrm{K}, \mathrm{Mg}$, Ca and $\mathrm{P}$ analyses, soil, ash or sediments $(10 \mathrm{~g})$ were shaken for $2 \mathrm{~h}$ with a mixture of $1 \mathrm{M} \mathrm{NH}_{4} \mathrm{Ac}$ and $0.005 \mathrm{M}$ DTPA as extracting solution (1:5 soil, ash or sediment: solution ratio); the extracts were filtered through cellulose paper and then analysed by simultaneous ICP-OES (Varian Vista Pro, Melbourne). All analyses were carried out in duplicate and the mean of both analyses was used in the statistical procedure.

\section{Statistical analysis}

Data on concentration and mass of nutrients in sediments from each erosion event were analysed by two-way ANOVA (with treatment and days after fire as factors), whereas the effects of soil stabilisation treatments on the accumulated mass of eroded sediments and nutrients were analysed by one-way ANOVA. After checking the equality of variances among groups with Levene's test, significant differences among the mean groups were established at $P<0.05$ using the Bonferroni's test for multiple comparisons (ANOVA-2) or the Tukey's test (ANOVA-1). With unequal variances, the original data were subjected to Cox-Box transformations to obtain homosce-dasticity and then significant differences among groups were assessed as previously explained. Simple regression models including soil properties (dependent variables) and the inverse of the accumulated precipitation (independent variable) were explored after checking the fulfilment of independence, homoscedasticity and normality assumptions. The best models were selected maximising the adjusted minimising the standard error of the estimated residues. Statistical procedures were performed with SPSS 15.0.

\section{Results}

\section{Main characteristics of sediments}

The two-way ANOVA for the $\mathrm{pH}$ of sediments, in $\mathrm{H}_{2} \mathrm{O}$ and $\mathrm{KC} 1$, showed that $72-73 \%$ of their variation was explained by time since fire, and the emergency stabilisation treatments have a 
Table 1. Results of the two-way ANOVA for the main sediment characteristics $\left(\mathrm{pH}, 8^{13} \mathrm{C}, 8^{15} \mathrm{~N}\right.$ and nutrient concentrations) with treatment (T) and days after fire (D) as factors

Probabilities are significant at *, $P<0.05$; **, $P<0.01$; **, $P<0.001$

\begin{tabular}{|c|c|c|}
\hline $\begin{array}{l}\text { Variable } \\
\text { (TxD) }\end{array}$ & $\begin{array}{l}\text { Treatment } \\
\text { partial } r \mid\end{array}$ & $\begin{array}{c}\text { Days after fire } \\
\text { partial } r \mid\end{array}$ \\
\hline $\mathrm{pHH}_{2} \mathrm{O}$ & $0.058^{*}$ & $0.732^{* * *}$ \\
\hline pHKCl & $0.057 *$ & $0717 * * *$ \\
\hline Total Cfekg-1 ${ }^{1}$ ) & $0.071^{*}$ & \\
\hline $8^{13} \mathrm{C}(\%)$, & $0.089 * *$ & $0.200^{*}$ \\
\hline Total N(gkg ') & $0.110^{* *}$ & \\
\hline $8^{15} \mathrm{~N}(\%)$, & & $0.810^{* * *}$ \\
\hline $\mathrm{NH} \mid-\mathrm{N}\left(\mathrm{mgkg}^{-1}\right)$ & $0.091^{* *}$ & $0.521^{* * *}$ \\
\hline $\mathrm{NO}^{\wedge}-\mathrm{NCmgkg}^{\prime 1}$ ) & $0.136 * *$ & $0.248^{* *}$ \\
\hline Extractable $\mathrm{Na}$ (mg kg ) & & $0.861^{* * *}$ \\
\hline Extractable K (mg kg ) & & $0.885^{* * *}$ \\
\hline Extractable $\mathrm{Mg}$ (mg kg ) & & $0.594 * * *$ \\
\hline Extractable Ca $\left(\mathrm{mgkg}^{-1}\right)$ & & $0.676^{* * * *}$ \\
\hline Extractable P (mg kg ) & & $0.592 * * *$ \\
\hline
\end{tabular}

Table 2. Significant regression models $(P<0.0005)$ between sediment properties as dependent variables $\left(\mathrm{pH}, 8^{15} \mathrm{~N}, \%\right.$; extractable nutrients, $\left.\mathrm{mg} \mathrm{kg}{ }^{-1}\right)$ and the accumulated precipitation $(x, \mathrm{~mm})$ or its inverse $\left(\mathrm{JC}^{-1}\right)$ as the independent variable

\begin{tabular}{lcl}
\hline Variable & $\boldsymbol{R}^{2}$ & Equation \\
\hline $\mathrm{pHH}_{2} 0$ & 0.52 & $\mathrm{y}=4.568+\left(271.1 \mathrm{x}^{1}\right)$ \\
$\mathrm{pHKCl}$ & 0.75 & $y=3.585+\left(312.4 \mathrm{x}^{\sim}\right)$ \\
$8^{15} \mathrm{~N}$ & 0.36 & $\mathrm{y}=1.385-\left(0.449 \mathrm{x} 10 \sim^{3} \mathrm{x}\right)+$ \\
& & $\left(3.529 \mathrm{x} 10 \sim^{7} \mathrm{x}^{2}\right)$ \\
Extractable Na & 0.74 & $y=32.73+\left(38500 \mathrm{x}^{\sim^{x}}\right)$ \\
Extractable K & 0.71 & $\mathrm{y}=47.03+\left(130054 \mathrm{x}^{1}\right)$ \\
Extractable Mg & 0.58 & $y=683.8-(0.219 \mathrm{x})$ \\
& 0.45 & $y=189.9+\left(144666 \mathrm{x}^{\prime 11}\right)$ \\
Extractable Ca & 0.56 & $y=1500-(0.458 \mathrm{x})$ \\
& 0.58 & $\mathrm{y}=416.4+\left(348329 \mathrm{x} \sim^{1}\right)$ \\
\hline
\end{tabular}

small but significant effect ( $<6 \%$ of variance explained: Table 1 ). The evolution of sediment $\mathrm{pH}$ during the study fitted to an inverse model with the accumulated precipitation as the independent variable, which explained 51 and $75 \%\left(\mathrm{pH}\right.$ in $\mathrm{H}_{2} \mathrm{O}$ and $\mathrm{KC} 1$ respectively) of the variance (Table 2). The $\mathrm{pH}$ of sediments, initially closer to that of ashes than to the burnt soil, decreased 1.2 units during the study, but after 13 months it remained slightly higher than that of the $0-5-\mathrm{cm}$ soil layer of the burnt plots just after the fire (Fig. 2a).

The C concentration of the sediments varied without a clear trend during the first 200 days of the study, with values close to that of ashes and 2-fold higher than those of unburnt and burnt topsoils (Fig. 2b). Despite a slight decrease in the last 6 months, $\mathrm{C}$ values in the sediments were still $70 \%$ higher than those in the topsoil at 13 months after the experimental fire. The two-way ANOVA showed no effect of date and a small, but significant, effect of treatment on sediment C $(7.1 \%$ of variance explained; Table 1$)$, with the highest values in $S\left(320 \pm 49 \mathrm{gkg} \sim^{1}\right)$, the lowest in $\mathrm{M}\left(285 \pm 39 \mathrm{gkg}^{1}\right)$ and intermediate in BS plots (304 \pm $\left.70 \mathrm{gkg} \sim^{1}\right)$. In all sediments, except the last collected, the $8^{13} \mathrm{C}$ was approximately that of ashes, with values $\sim 1 \%$ o more negative than in the $0-5$-cm layer of unburnt and burnt soil (Fig. 2c). Treatment and days after fire had significant effects on sediment $8 \mathrm{C}$, respectively explaining 8.9 and $20.0 \%$ of its variance (Table 1 ). The highest $8^{13} \mathrm{C}$ values were found in $\mathrm{M}(-27.9 \pm 0.4 \% \mathrm{o})$ and the lowest in $\mathrm{S}$ plots $(-28.1$ $\pm 0.3 \%$ o), with BS plots $(-27.9 \pm 0.3 \% 0)$ in an intermediate position; only at the end of the study the sediments $8{ }^{13} \mathrm{C}$ became less negative, approaching values for burnt and unburnt topsoils.

Only small fluctuations were detected in sediment $\mathrm{N}$ concentration during the whole study, most values being similar to those of ashes and 50-70\% higher than those of burnt and unburnt topsoils $(0-5 \mathrm{~cm})$ (Fig. $2 d)$. As also happens with $\mathrm{C}$ values, the two-way ANOVA showed no effect of time after fire and a small, but significant, effect of treatment on sediment $\mathrm{N}$ concentration (11\% of variance explained; Table 1), with the highest values in S $\left(23.9 \pm 3.2 \mathrm{gkg}^{-1}\right)$, the lowest in $\mathrm{M}\left(21.1 \pm 3.1 \mathrm{gkg}^{-1}\right)$ and intermediate in BS plots $\left(22.7 \pm 4.8 \mathrm{~g} \mathrm{~kg}^{-1}\right)$. Conversely, the $8{ }^{15} \mathrm{~N}$ of sediments was not affected by the emergency stabilisation treatments considered, but it was largely influenced by days after fire ( $81 \%$ of variance explained; Table 1 ), rising $~ 1 \%$ from values similar to those of ashes in the first three samplings until values progressively closer to those of the burnt soil in the second half of the study, with an intermediate and sudden decrease in months two to three (Fig. 2e). Such reduction in late autumn-early winter, not related to the amount of eroded sediments, seemed to be influenced by the high rainfall in this period; without runoff analyses it is not possible to verify if this reduction in sediments 8 $\mathrm{N}$ is related with changes in dissolved organic matter quantity or quality. For the whole study, the evolution of sediment $8^{15} \mathrm{~N}$ fitted to a quadratic model with accumulated precipitation as the independent variable, explaining $36 \%$ of the variance (Table 2). Except at $t=141$ days, whenBS $>\mathrm{S}$, there were no significant differences for $8 \mathrm{~N}$ among treatments.

The $\mathrm{NFL}^{\wedge}-\mathrm{N}$ was the dominant form of inorganic $\mathrm{N}$ in sediments (>96\%) and during most of the study its concentration $\left(100-250 \mathrm{mgkg}^{-1}\right)$ largely exceeded that in the unburnt topsoil (12mgkg ), being closer to the burnt topsoil $\left(85 \mathrm{mgkg}^{-1}\right)$ than to ashes (344mgkg $\sim^{1}$ ). The two-way ANOVA showed significant effects of treatment, time after fire and their interaction (with respectively $9.1,52.1$ and $36.9 \%$ of variance explained), with significant differences among treatments (lowest values in $\mathrm{M}$ ) only in the last three erosion events (Fig. 2f).

Nitrate concentration in sediments was low and always lower than in unburnt and burnt topsoils and ashes (Fig. 3a). Both treatment and days after fire had a significant effect on $\mathrm{NO}^{\wedge}-\mathrm{N}$ concentration (13.6 and $24.8 \%$ of variance explained, Table 1 ), with the highest values in control $(8.6 \pm 4.0 \mathrm{mgkg} \sim)$, the lowest in M (6.2 $\left.\pm 3.3 \mathrm{mgkg}^{-1}\right)$ and intermediate in $\mathrm{S}$ plots $\left(7.7 \pm 3.9\right.$ mgkg $\left.^{-1}\right)$.

The most abundant extractable base cation in the sediments was $\mathrm{Ca}$, followed by $\mathrm{Mg}$ and $\mathrm{K}$. Extractable base cation concentrations were affected neither by the emergency stabilisation treatment nor by the treatment $\mathrm{x}$ days after fire interaction, but they were largely influenced by the time since fire $(59-89 \%$ of variance explained; Table 1). During the first samplings, 
(a)

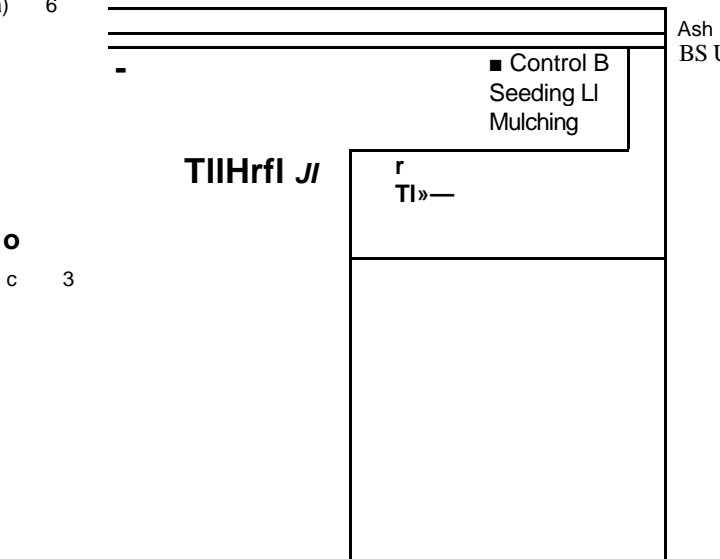

$2742485792110141174201242 \quad 340394$

(C) $-25 \mathrm{~T} \mid \mathrm{T}$

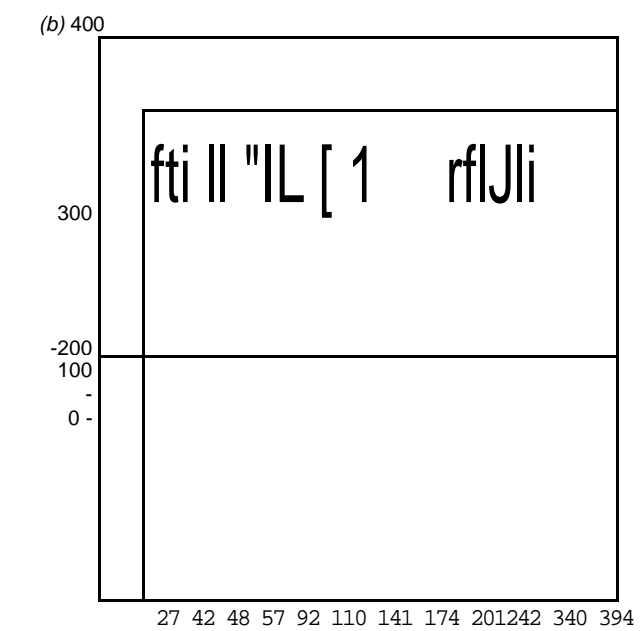

Ash

US BS

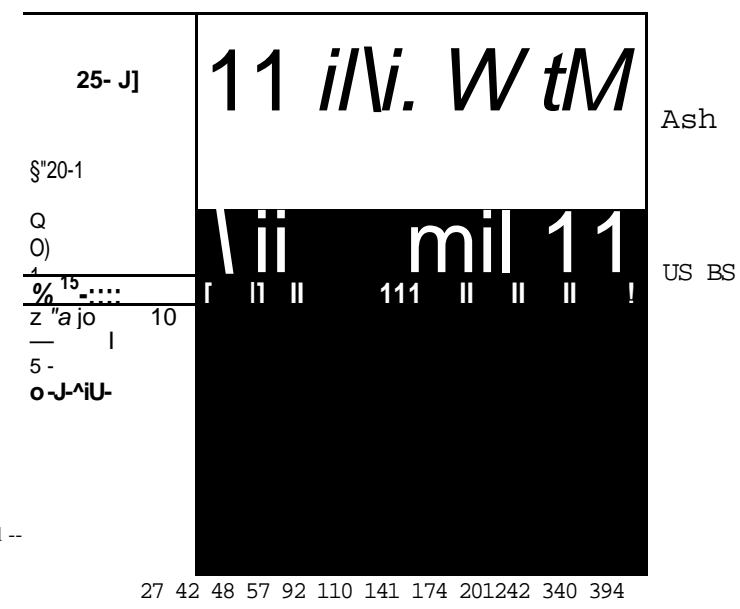

(e)

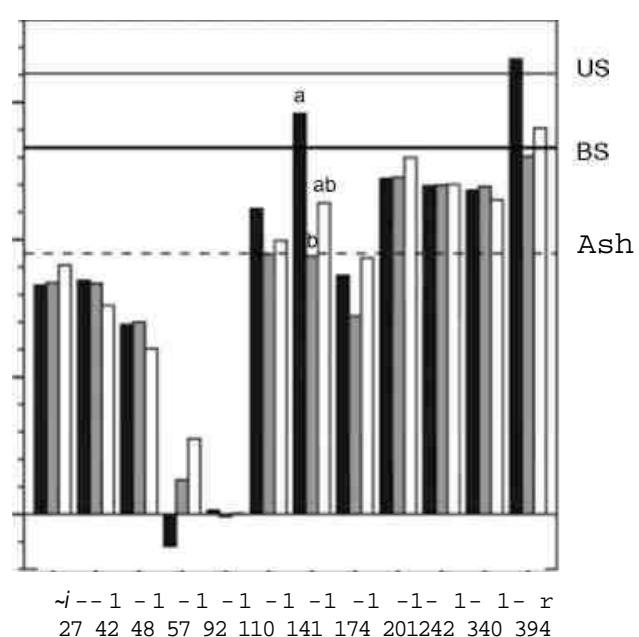

$(\odot$

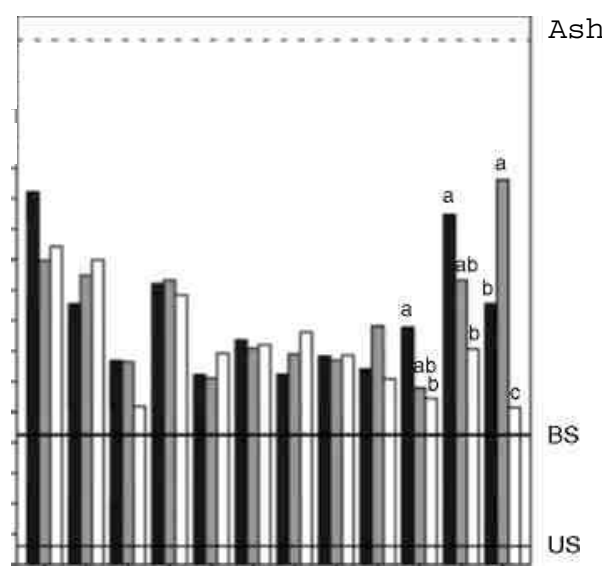

$2742 \quad 485792 \quad 110141174201242 \quad 340394$

Days after fire

Fig. 2. Evolution of main characteristics of the sediments eroded during the first 13 months after the experimental fire in the control, seeding and mulching treatments: $(a) \mathrm{pH}_{\mathrm{K}} \mathrm{Cb}(\&)$ total $\mathrm{C}$ concentration; (c) $8 \mathrm{C}$; (d) total $\mathrm{N}$ concentration; (e) $8 \mathrm{~N}$ and if) $\mathrm{NH} \wedge$ - $\mathrm{N}$ concentration. Horizontal lines show the reference values in ash, unburnt soil (US) and burnt soil (BS) at the beginning of the study (i.e. after the experimental fire andbefore the application of soil stabilisation treatments). For a given date, different letters (a, b, c,...) indicate statistically significant differences $(P<0.05)$ among treatments. 

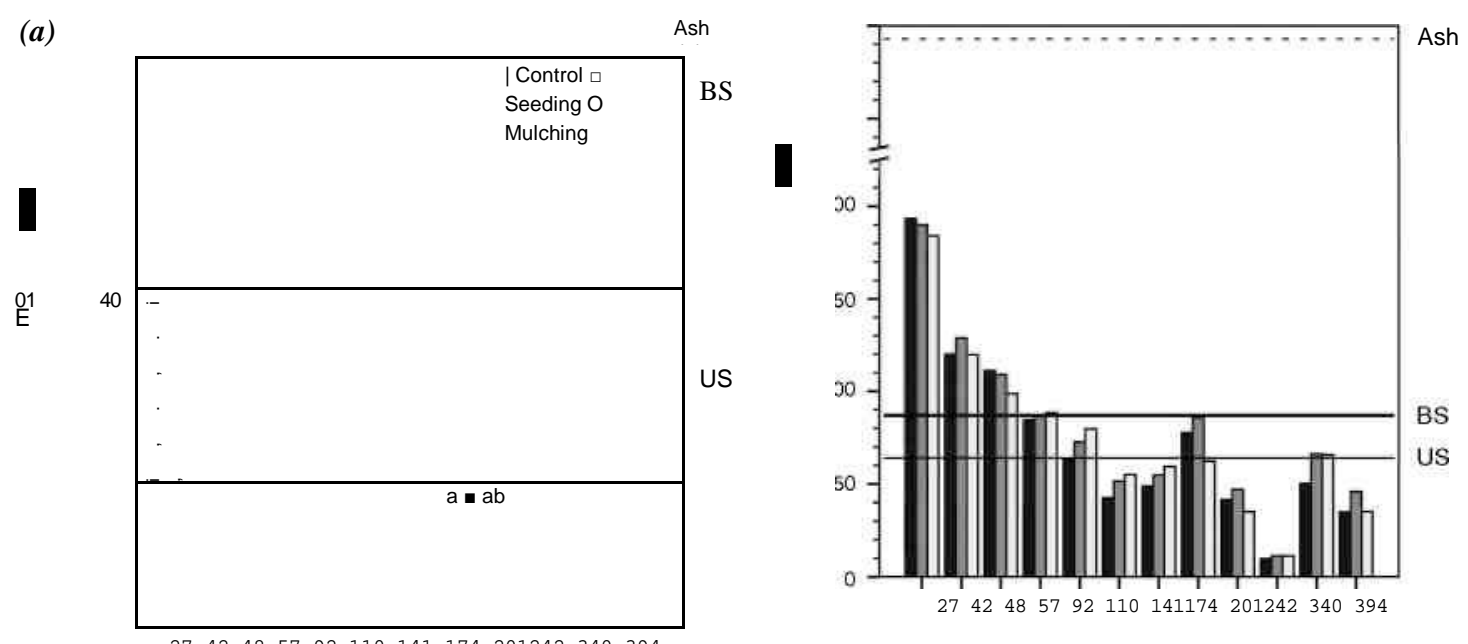

(C) 3500

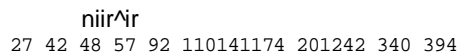
Ash

LU

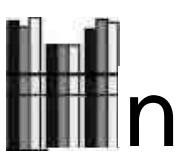

BS US
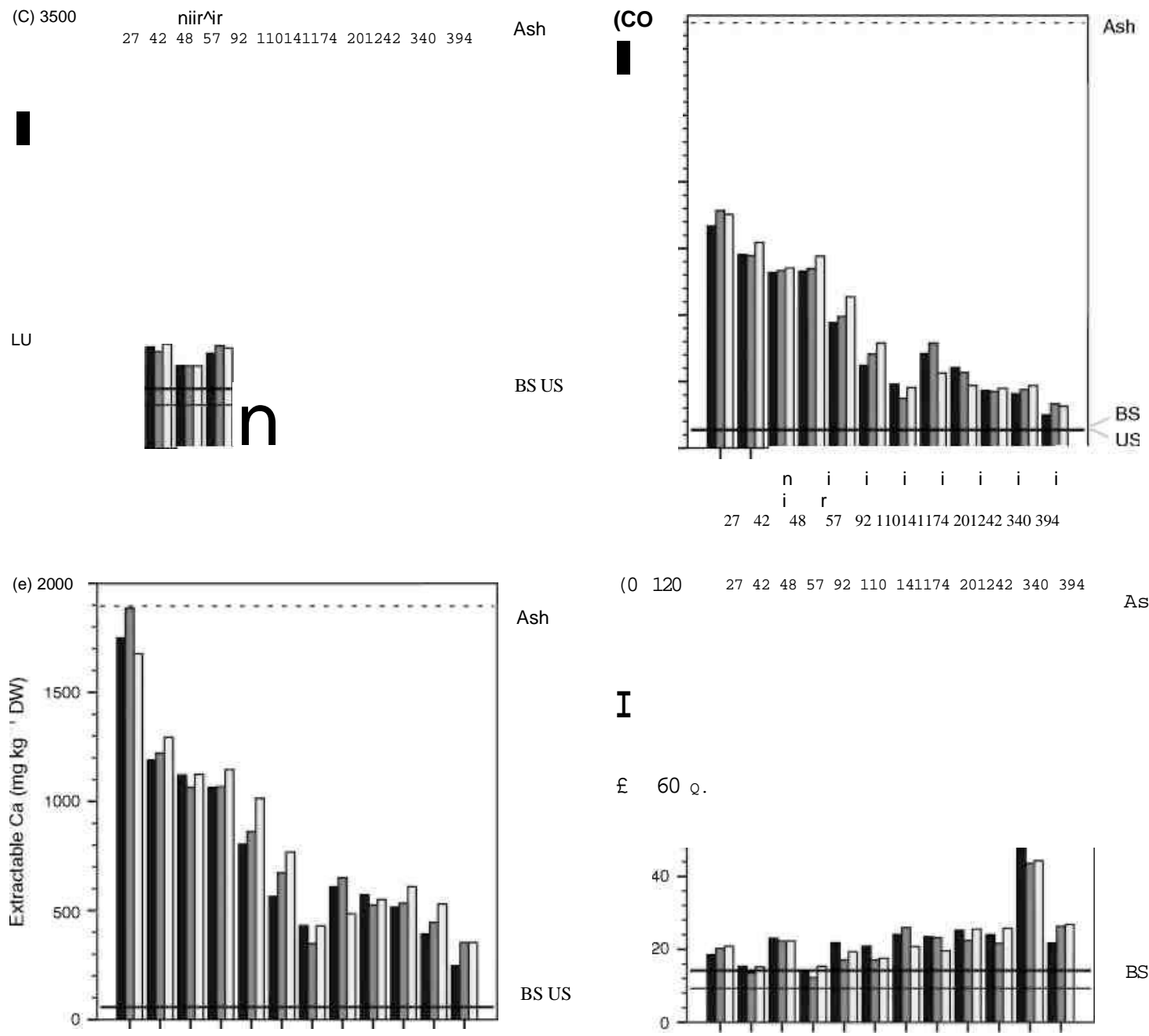

(๑ $120 \quad 2742 \quad 485792 \quad 110141174 \quad 201242 \quad 340 \quad 394$

Ash Ash

\section{I}

$£ \quad 60 \mathrm{Q}$.

BS US

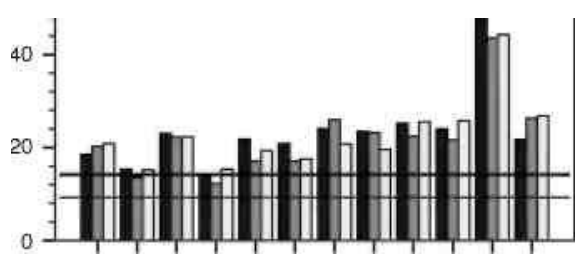

BS US

Days after fire

Fig. 3. Evolution of nutrient concentrations in the sediments eroded during the first 13 months after the experimental fire in the control, seeding and mulching treatments: (a) NO^-N; (b) extractable Na; (c) extractable K; (d) extractable Mg; (e) extractable Ca and if) extractable P. Horizontal lines show the reference values in ash, unburnt soil (US) and burnt soil (BS) at the beginning of the study (i.e. after the experimental fire and before the application of soil stabilisation treatments). For a given date, different letters (a, b, c,...) indicate statistically significant differences $(P<0.05)$ among treatments. 
extractable $\mathrm{Na}$ and $\mathrm{K}$ concentrations in sediments were above those in burnt topsoils but, from 92 days after the experimental fire, most of the values were below those of the topsoils (Fig. $3 b, c$ ). The initial extractable $\mathrm{Mg}$ concentration in sediments was half of that in ashes but 13-fold that in topsoils and, despite a steady decline with time, at the end of the study it was twice that in the topsoil (Fig. 3d). Similar temporal evolution was observed for extractable Ca concentration in sediments, from initial concentrations similar to those of ashes (35 times that of topsoil) until values at the end of the study that were still 5.5 times higher than in the topsoil (Fig. 3e). Curvilinear inverse regression models, explaining $56-74 \%$ of the variance, were found for extractable $\mathrm{Na}, \mathrm{K}, \mathrm{Mg}$ and $\mathrm{Ca}$ in sediments with the accumulated precipitation as the independent variable (Table 2). For extractable Mg and Ca, linear regression models were also found with the accumulated precipitation, which explain approximately half of the variance (Table 2). Contents of extractable $\mathrm{P}$ in sediments were low (six times less than in ashes) and showed little variation during the study, except for a transient increase 340 days after the fire (i.e. in

Table 3. Results of the two-way ANOVA for the mass of sediments and nutrients with treatment $(\mathrm{T})$ and days after fire $(\mathrm{D})$ as factors

Probabilities are significant at *, $P<0.05$; **, $P<0.01$; **, $P<$ 0.001

Treatment Days after fire Interaction (T x D) partial $r$ partial $r \mid$ partial $r$

\begin{tabular}{|c|c|c|c|}
\hline Sediments (kg ha & $0.808^{* * * *}$ & $0.882 * * *$ & $0.607^{* * *}$ \\
\hline Total C (kg ha"') Total & $0.802 * * *$ & $0.830 * * *$ & $044 \wedge * * *$ \\
\hline $\mathrm{N}\left(\mathrm{kg} \mathrm{ha}^{-1}\right)$ & $0.534^{* * *}$ & $0.793^{* * *}$ & $0.330 *$ \\
\hline $\mathrm{NH} \mid-\mathrm{N}\left(\mathrm{gha}^{-1}\right)$ & $0.756^{* * *}$ & $0.786 * * *$ & $0.423^{* * *}$ \\
\hline $\left.\mathrm{NO}^{\wedge}-\mathrm{N}^{\wedge} \mathrm{ha}^{-1}\right)$ & $0.695 * * *$ & $0.742 * * *$ & $0.355^{* * *}$ \\
\hline Extractable $\mathrm{Na}$ (g ha ) & $0.732 * * *$ & $0.829 * * *$ & $0.560^{* * *}$ \\
\hline Extractable K (g ha ) & $0.734^{* * *}$ & $0.817 * * *$ & $0.565^{* * *}$ \\
\hline Extractable Mg (g ha ) & $0.681^{* * *}$ & $0.768 * * *$ & $0.289 * *$ \\
\hline Extractable Ca (g ha ) & $0.696^{* * *}$ & $0749 * * *$ & $0.314^{* * *}$ \\
\hline Extractable P (g ha ) & $0.720 * * *$ & $0774^{* * *}$ & $0.389 * * *$ \\
\hline
\end{tabular}

autumn, a temperate humid period in the study area), most values being slightly higher than in burnt topsoils (Fig. 3f). Time since fire, but not treatment, influenced the sediment extractable $\mathrm{P}$ concentrations (59\% of variance explained: Table 1).

\section{Mass of nutrients lost with sediments}

The sediment mass was largely influenced by the treatment and time after fire ( 81 and $88 \%$ of respective variance explained), but the interaction of these variables, which explained $61 \%$ of the variance, showed a stronger effect for B S and S plots than for $M$, whose values were more stable during the study period (Table 3). Very similar results were obtained for the amount of extractable $\mathrm{Na}$ and $\mathrm{K}$ lost with sediments (Table 3). The same was true for the other nutrients, although the interaction between factors was less important (29-44\% of variance explained); for total $\mathrm{N}$ the treatment effect was also lower (53\% of variance explained; Table 3).

Compared with the BS control, at the end of the study period the accumulated mass of sediments (BS, $3897 \pm 1012 \mathrm{kgha}^{-1}$; S, $3117 \pm 612 \mathrm{kgha}^{-1}$; M, $381 \pm 194 \mathrm{~kg} \mathrm{ha"}^{11}$ ) and extractable nutrients lost with them (Table 4) were only $9-15 \%$ in $\mathrm{M}$ and $66-88 \%$ (but 96-100\% for total C and N) in S; differences between M and BS or S were significant at $P<0.01(P<0.05$ for NOF-N).

As shown in Table 4, the extractable nutrients lost by erosion accounted for $0.14-2.2 \%$ of ash extractable nutrients in $\mathrm{M}$, significantly less than the $0.88-25.2 \%$ and $1.25-25.2 \%$ respectively found in S and BS; in all treatments, the percentages were high for total $\mathrm{C}$ and $\mathrm{N}$, intermediate for $\mathrm{NH} \mid-\mathrm{N}, \mathrm{Ca}, \mathrm{P}$ and $\mathrm{Mg}$, and low for $\mathrm{NO}^{\wedge}-\mathrm{N}, \mathrm{Na}$ and $\mathrm{K}$. If extractable nutrients in ash+topsoil was taken as a reference, nutrient losses by erosion were negligible in $\mathrm{M}$ (from $0.01 \%$ to $0.39 \%$ ); the same was true for $\mathrm{NO}^{\wedge}-\mathrm{N}, \mathrm{Na}$ and $\mathrm{K}$ in $\mathrm{S}$ and $\mathrm{BS}$ plots (from $0.13 \%$ to $0.44 \%$ ), whereas values were $\sim 1 \%$ for total $\mathrm{C}$, total $\mathrm{N}, \mathrm{NFF} \mid \mathrm{N}$ and $\mathrm{P}$, and 2-4 times higher for $\mathrm{Mg}$ and $\mathrm{Ca}$.

Table 4. Accumulated mass of sediments and nutrientes lost by erosion in the plots under each treatment (C, control; S, seeding; M, mulching) and percentage of nutrients in ash and ash+topsoil they accounted for

In each row, different letters showed statistically significant differences between treatments for each variable: (i) mass of sediments or nutrients; (ii) percentage of ash nutrients lost by erosion and (iii) percentage of ash+topsoil nutrients lost by erosion

\begin{tabular}{|c|c|c|c|c|c|c|c|c|c|}
\hline \multirow[t]{2}{*}{$\begin{array}{l}\text { Variable } \\
\text { nat }\end{array}$} & \multicolumn{2}{|c|}{ Mass of sediments and nutrients lost } & \multirow{2}{*}{$\begin{array}{c}\text { by erosion } \\
\mathrm{M}\end{array}$} & \multicolumn{2}{|c|}{ Ash nutrients lost by } & \multirow{2}{*}{$\begin{array}{c}\text { erosion } \\
\mathrm{M}\end{array}$} & \multirow{2}{*}{$\begin{array}{c}\text { Ash+topsoil } \\
\text { C }\end{array}$} & \multicolumn{2}{|c|}{ nutrients by erosion } \\
\hline & $\mathrm{C}$ & $\begin{array}{c}\text { S } \\
\left(\text { kgha- }^{1}\right)\end{array}$ & & $\mathrm{C}$ & $\begin{array}{c}\mathrm{S} \\
(\%)\end{array}$ & & & $\begin{array}{c}S \\
(\%)\end{array}$ & M \\
\hline Sediments & $3897 "$ & 3117" & $381 "$ & & & & & & \\
\hline Total C & 1028" & 989" & 100" & 22.90" & 22.0" & 2.23" & $1.15 "$ & 1.11" & $0.11 "$ \\
\hline Total N & 76.8" & $\begin{array}{c}77.0^{\prime \prime} \\
\text { (gha- }^{1} \text { ) }\end{array}$ & 7.67" & $25.2^{\prime \prime}$ & $\begin{array}{l}25.2^{\prime \prime} \\
(\%)\end{array}$ & $2.51 "$ & $1.04 "$ & $\begin{array}{l}1.04 " \\
(\%)\end{array}$ & $0.10^{\prime \prime}$ \\
\hline $\mathrm{NHj}-\mathrm{N}$ & $548 "$ & $476 "$ & 53.5" & 12.3" & $10.7 "$ & $1.20 "$ & $1.16 "$ & $1.01 "$ & $0.11 "$ \\
\hline $\mathrm{NO}^{\wedge}-\mathrm{N}$ & 37.1" & $32.6 "$ & 2.92" & 3.66" & $3.21 "$ & $0.29 "$ & $0.15 "$ & $0.13 "$ & $0.01 "$ \\
\hline Extractable $\mathrm{Na}$ & 232" & 194" & 21.5" & $1.53 "$ & $1.28 "$ & $0.14 "$ & $0.39 "$ & $0.33 "$ & $0.04 "$ \\
\hline Extractable $\mathrm{K}$ & $557 "$ & 393" & 51.2" & $1.25 "$ & $0.88 "$ & $0.12 "$ & $0.44 "$ & $0.31 "$ & $0.04 "$ \\
\hline Extractable Mg & 1101" & 861" & 94.6" & 6.68" & 5.22" & $0.57 "$ & 2.50" & 1.95" & $0.21 "$ \\
\hline Extractable Ca & 2387" & 1900" & 211" & 9.76" & 7.77" & $0.86 "$ & 4.41" & 3.51" & $0.39 "$ \\
\hline Extractable $\mathrm{P}$ & 89.4" & 58.8" & 8.82" & 7.44" & 4.89" & $0.73 "$ & $1.08 "$ & $0.71 "$ & $0.11 "$ \\
\hline
\end{tabular}




\section{Discussion}

Considering the strong relationship between $\mathrm{pH}$ and accumulated precipitation, the progressive acidification of sediments during the study ( 0.5 units higher than that reported by Robichaud et al. 2006) showed that the oxides and carbonates of basic ions supplied by ashes (Certini 2005), as well as soil exchangeable cations, were steadily lost by leaching and runoff. A minor effect of emergency stabilisation treatments on sediment $\mathrm{pH}$ coincides with results of Robichaud et al. (2006).

The $\mathrm{C}$ concentration in sediments, which exceed the range of 110-244 gkg reported by Thomas et al. (1999), was higher than in burnt topsoils and close to that in ashes. This result suggests that, during most of the study period, sediments were mainly contributed by charred plant and litter material, agreeing with de Koff et al. (2006) who indicated that C concentration increased immediately after a low severity prescribed fire, probably because of C-rich ashes in sediments. Stabilisation treatments had small effects on sediment $\mathrm{C}$ concentration, with the lowest values in mulching plots. Except for with mulching, the accumulated amount of $\mathrm{C}$ in the sediments was 5-fold those after high and moderate intensity experimental fires in eastern Spain (Gimeno-Garcia et al. 2000) and it slightly exceeded the highest value $\left(900 \mathrm{kgha}^{-1}\right)$ observed the first year after high severity wildfires (Baird et al. 1999; Spigel and Robichaud 2007). This result suggested that, whereas low intensity prescribed fires reduce nutrient losses by volatilisation relative to wildfires, they expose available nutrients to erosion (de Koff et al. 2006). In seeding and control plots, the eroded $\mathrm{C}$ during the study accounted for $25 \%$ of the ash $\mathrm{C}$ and $1 \%$ of the ash+topsoil $\mathrm{C}$ pool, these values being 10 -fold lower in mulching plots. Baird et al. (1999) also estimated that $1 \%$ of $\mathrm{C}$ from the A-horizon was lost through post-fire erosion. Data on $8^{13} \mathrm{C}$ in sediments, similar to that of ashes and different from those of unburnt and burnt topsoils, also suggested that our sediments were mainly charred plant and litter material.

Nitrogen concentration in sediments (similar to that in ashes and higher than in burnt and unburnt topsoils) was at least twice that reported by Thomas et al. (1999) for eucalypt and pine plantations, likely due to differences in vegetation cover in the present study (leguminous shrubland). As for C, stabilisation treatments had little effect on sediment $\mathrm{N}$ concentration, as also indicated Thomas et al. (2000) for a litter treatment, lowest values being observed with mulching. Accumulated losses of $\mathrm{N}$ in seeding and control plots largely exceeded the usual range in burnt soils (14-57kgha ${ }^{1}$ year ${ }^{-1}$ : Debano and Conrad 1978: Helvey et al. 1985; Soto et al. 1997; Baird et al. 1999; Thomas et al. 1999; Gimeno-Garcia et al. 2000; Lane et al. 2008), being only below the highest values reported for high severity wildfires (100-129kg ha': SotoefaZ. 1997; Spigel and Robichaud 2007); with mulching the mass of total $\mathrm{N}$ eroded was only half of the lowest values. Because there was little treatment effect on sediment $\mathrm{N}$ concentration, the mulching effectiveness in reducing the amount of $\mathrm{N}$ lost was mainly due to the reduction in soil erosion as reported by Soto et al. (1997) and Spigel and Robichaud (2007). As for C, the eroded N during the first year accounted for $25 \%$ of ash $\mathrm{N}$ and $1 \%$ of ash+topsoil $\mathrm{N}$ pool in seeding and control plots, but 10 -fold less in mulching plots; the latter figure for seeding and control plots was below the $2 \%$ reported for topsoils (0-10 cm) after high severity wildfires (Baird et al. 1999; Thomas et al. 1999). By contrast with data on $\mathrm{C}$ and $\mathrm{N}$ concentrations and $8 \mathrm{C}$, the sediment $8 \mathrm{~N}$ was strongly influenced by days after fire, increasing from initial values similar to ashes to final values close to the burnt topsoil following a quadratic model with the accumulated precipitation as the independent variable. These results suggest that, over time, sediment $8^{15} \mathrm{~N}$ was affected by losses of soluble $\mathrm{N}$ (likely NOiT-) relatively depleted in ${ }^{15} \mathrm{~N}$.

The $\mathrm{NH}^{\wedge}-\mathrm{N}$ accounted for most of the inorganic $\mathrm{N}$ in burnt topsoil, ashes and sediments, agreeing with the results of Gimeno-Garcia et al. (2000), but not with those of Robichaud and Brown (1999) and Robichaud et al. (2006). As also reported by Andreu et al. (1996) for mineral N, sediments were enriched in $\mathrm{NHj}-\mathrm{N}$ relative to burnt (1.2-3 times) and unburnt (12-23 times) topsoil. Differences in $\mathrm{NH}^{\wedge}-\mathrm{N}$ concentration among treatments (lowest values for mulching) were only observed in the second half of our study and, despite the significant effect of time after fire, no clear temporal trend was identified. During the first year, accumulated losses of $\mathrm{NH}^{\wedge}-\mathrm{N}$ by erosion with mulching were within the usual range (50-140 $\mathrm{mgkg}^{-1}$ : Robichaud and Brown 1999; Gimeno-Garcia et al. 2000; Robichaud et al. 2006), whereas values in control and seeding plots exceeded 3-4 times that range. Although 14\% lower, total NH4 -N losses with seeding did not differ significantly from those in control plots; Robichaud et al. (2006) also found no effects of seeding.

The low $\mathrm{NO}^{\wedge}-\mathrm{N}$ concentration in the sediments contrasted with the results of Robichaud and Brown (1999) and Robichaud et al. (2006), but coincided with those of Gimeno-Garcia et al. (2000) and was an expected result: the runoff water that triggers erosion likely washed the sediments in the trap, carrying off the highly soluble $\mathrm{NO}^{\wedge}-\mathrm{N}$. The lack of significant effects of seeding and of a discernible trend with time for nitrate concentration in sediments agreed with the findings of Robichaud et al. (2006). Compared with other published data (50-810gha ${ }^{-1}$ year $^{1}$ : Robichaud and Brown 1999; Gimeno-Garcia et al. 2000; Robichaud et al. 2006), the accumulated amount of eroded $\mathrm{NO}^{\wedge}-\mathrm{N}$ in control and seeding plots were 2-20 times lower (15-250 fold lower with seeding); this result can be explained by the wide differences among study areas for annual precipitation, which was 2-7 times higher in our case $(3036 \mathrm{~mm}$ v. 400-1600 $\mathrm{mm}$ ) and likely washed the $\mathrm{NO}^{\wedge}-\mathrm{N}$ of sediments retained in the sediment fences.

The concentration of soluble base cations in the sediments was lowest for $\mathrm{Na}$, intermediate for $\mathrm{K}$ and $\mathrm{Mg}$, and highest for $\mathrm{Ca}$, following the typical order of magnitude (de Koff et al. 2006) and reflecting the high solubility of $\mathrm{Na}$ and $\mathrm{K}$ relative to $\mathrm{Ca}$ and $\mathrm{Mg}$, in ashes (Khanna et al. 1994).

In the first sediments collected, the extractable Na concentration was three times higher than in the unburnt topsoil, agreeing with findings of de Koff et al. (2006). Likely due to its high solubility, the extractable $\mathrm{Na}$ concentration in sediments decreased rapidly as a function of accumulated precipitation and from 3 months after fire it fell below that in recently burnt topsoil. The accumulated amount of extractable Na lost with sediments in control and seeding plots was higher than that reported by Gimeno-Garcia et al. (2000), but 15 times lower 
than that observed by Debano and Conrad (1978) after a prescribed fire. Over the first year, particulate losses of extrac-table $\mathrm{Na}$ were less than $2 \%$ of the ash $\mathrm{Na}$ and $0.4 \%$ of the ash+topsoil Na extractable pool in seeding and control, and negligible (ash $\mathrm{Na}, 0.14 \%$; ash+topsoil $\mathrm{Na}, 0.01 \%$ ) in mulching plots.

Although the extractable K concentration in ashes was 10-fold more than that reported by Thomas et al. (1999), in the first sediments it was in the upper part of the range (200-520 $\mathrm{mgkg}^{-1}$ ) found by Robichaud and Brown (1999) and Thomas et al. (1999), but below the $1619 \mathrm{mgkg}^{-1}$ observed by de Koff et al. (2006) immediately after fire. Like $\mathrm{Na}$, the highly soluble extractable $\mathrm{K}$ in sediments decreased rapidly as a function of accumulated precipitation during the first 3 months after fire. One year after fire, the accumulated amount of extractable $\mathrm{K}$ lost with sediments was medium to low compared with the usual range $(0.3-2.9 \mathrm{~kg}$ ha $^{-1}$ : Robichaud and Brown 1999; Thomas et al. 1999; Gimeno-Garcia et al. 2000; Robichaud et al. 2006), but far from the highest losses that have been reported (19-30 kg ha-1: Debano and Conrad 1978; Spigel and Robichaud 2007). Agreeing with Thomas et al. (2000) and Robichaud et al. (2006) respectively, mulching and seeding had little effect on sediment $\mathrm{K}$ concentrations; consequently, mulching reduced $\mathrm{K}$ losses with sediments by reducing soil erosion, as found by Thomas et al. (2000). In the study of Thomas et al. (1999), the particulate losses of $\mathrm{K}$ with sediments during the first year accounted for 11.0 and $3.7 \%$ of total $\mathrm{K}$ (in the $0-3$ - and $0-10$-cm soil layers respectively), whereas in the present study they represented only $1 \%$ of $\mathrm{K}$ in ashes and less than $0.5 \%$ of that in ashes+topsoil, being negligible in mulching $(<0.12 \%)$.

The extractable Mg concentration in the first sediments was 13-fold higher than that in burnt or unburnt topsoils; this enrichment ratio decreased to 10 in the three subsequent erosion events, still well above that (4-fold) obtained by de Koff et al. (2006) for sediments before and immediately after fire. Unlike for monovalent cations, the progressive decrease of Mg concentration in sediments can be adjusted to curvilinear inverse and linear regression models with the accumulated precipitation, and sediment $\mathrm{Mg}$ concentration 1 year after fire was still twice that in topsoils, disagreeing with de Koff et al. (2006) who found that exchangeable base cations resumed pre-fire levels 7 months after fire. Accumulated losses of extractable $\mathrm{Mg}$ in control and seedingtreatmentswerewithintherange(0.8-1.4kgha year ${ }^{-}$) observed by Gimeno-Garcia et al. (2000), but below the highest values reported (10-28kgha^year ${ }^{\wedge} \wedge$ Spigel and Robichaud 2007; Debano and Conrad 1978). Magnesium losses with sediments from control and seeding plots accounted for 5.2-6.7\% and $2-2.5 \%$ of the respective extractable $\mathrm{Mg}$ pool in ashes and ashes+topsoil, whereas in mulching plots they were 10-fold lower.

In the sediments eroded the first month after fire, irrespective of treatment, the extractable Ca concentration was 30-fold higher than that in burnt or unburnt topsoils; during the following 2 months this enrichment ratio decreased to 20, still much higher than that indicated by de Koff et al. (2006) for sediments before and immediately after fire. Like $\mathrm{Mg}$, the steady decline with time of sediment Ca concentration fitted to curvilinear inverse and linear regression models with the accumulated precipitation and after 1 year it was still five times higher than that in topsoils, showing a much longer-lasting effect of the prescribed fire than that reported by de Koff et al. (2006). The accumulated amounts of extractable Ca lost with sediments in control and seeding plots were at the bottom of the published range (2-200 kg ha ${ }^{1}$ year $^{-1}$ : Debano and Conrad 1978; Gimeno-Garcia et al. 2000; Spigel and Robichaud 2007). Nevertheless, the accumulated Ca losses had a high relative importance in our study, accounting for $7.8-9.8 \%$ and $3.5^{\wedge} 1.4 \%$ of the respective extractable $\mathrm{Ca}$ pool in ashes and ashes+topsoil; as with other nutrients, Ca losses with mulching were 10 -fold lower.

Except for one of the last samplings, the extractable $\mathrm{P}$ concentration in sediments was approximately half the lowest value (50-300 $\mathrm{mgkg}^{-1}$ ) observed by Thomas etal. (1999)andit did not decrease over time, contrary to other studies (Thomas et al. 1999; Robichaud et al. 2006). As also reported by Saa et al. (1994), sediments were 3-5 times enriched in available P relative to soil. However, extractable $\mathrm{P}$ concentration in sediments was lower than in ashes, possibly due to $\mathrm{P}$ insolubilisa-tion, as a consequence of increased cation concentration and $\mathrm{pH}$, or to $\mathrm{P}$ adsorption on clay or Fe-oxide surfaces, as Stephens et al. (2004) suggested for the lack of $\mathrm{P}$ increase in stream water after a prescribed fire. Although higher than the 14gha year- found by Helvey etal. (1985), the accumulated losses of extractable P were below the reported range (117-8 $30 \mathrm{~g}_{\text {ha }}{ }^{1}$ year $^{-1}$ : Thomas etal. 1999; Gimeno-Garcia etal. 2000; Robichaud et al. 2006). However, these losses were relevant in control and seeding plots because they accounted for $4.9-7.4 \%$ of the extractable P pool in ashes.

It is generally held that post-fire erosion could affect downstream water quality and sedimentation, but not long-term site productivity (Helvey et al. 1985; Emmerich 1999; Robichaud etal. 2006), because nutrients lost with the eroded sediments are typically negligible compared with soil reserves (Means et al. 1992; Busse 1994; Baird et al. 1999), outputs from burning (Feller 1988), or inputs with ash after wildfires (Grier 1975; Robichaud et al. 2006). However, the present study showed that, at least in steep areas in a humid climate, even a fire of low to moderate severity can lead to substantial accumulated losses of $\mathrm{C}$, $\mathrm{N}$ and $\mathrm{NH}^{\wedge}-\mathrm{N}$ with the eroded sediments, as well as a noticeable fraction of the extractable $\mathrm{Ca}$ and $\mathrm{Mg}$ pools in ashes and topsoil. Under the described scenario, particulate losses of $\mathrm{NO}^{\wedge}-\mathrm{N}, \mathrm{Na}$ and $\mathrm{K}$ were less important. However, it must be highlighted that this can be due to high losses of these nutrients in soluble forms, as suggested by the differences (10-fold for $\mathrm{NO}^{\wedge}-\mathrm{N}$; 6 -fold for $\mathrm{Na}$ and $\mathrm{K}$ ) between their respective concentrations in ashes and sediments from the first erosion event, which were much higher than those for less soluble divalent cations (no difference for Ca; 2-fold for Mg). Consequently, our results agreed with the advice that post-fire soil quality might be seriously affected through preferential loss of fines and organic matter, both of which contain more nutrients than does the remainder of the soil (Thomas etal. 1999; Shakesby etal. 2002), especially in the case of recurrent fires in areas where they are not a natural disturbance for ecosystems.

\section{Conclusions}

Little or no effect of treatments on nutrient concentration in sediments was found. Data on $\mathrm{C}, \mathrm{N}$ and $8{ }^{13} \mathrm{C}$ indicate that our 
sediments were mainly charred plant and litter material. During the study, the high concentrations of $\mathrm{C}, \mathrm{N}$ and $\mathrm{NH}^{\wedge}-\mathrm{N}$ in sediments varied little Those of $\mathrm{Mg}$ and Ca decreased progressively without reaching their reference topsoil values, which were reached by $\mathrm{Na}$ and $\mathrm{K}$ within 3 months; $\mathrm{NO}^{\wedge}-\mathrm{N}$ concentration in sediments was low and stable.

In all treatments, the fraction of available ash nutrient lost by erosion was high for $\mathrm{C}$ and $\mathrm{N}$ (22-25\%), intermediate for NHl-N, $\mathrm{Ca}, \mathrm{P}$ and $\mathrm{Mg}(5-12 \%)$, and low for $\mathrm{NO}^{\wedge}-\mathrm{N}, \mathrm{Na}$ and $\mathrm{K}(1-4 \%)$, although the result for the latter three nutrients may have been due to high losses in solution. Compared with control plots, seeding slightly reduced the accumulated losses of nutrients with sediments, which were decreased 10 -fold by mulching. Because emergency stabilisation treatments had little effect on cation concentrations in sediments, the low cation losses in mulching plots was a consequence of erosion reduction.

\section{Acknowledgements}

We thank Jorge Benitez, and M. Teresa Perez for technical assistance in the laboratory. This research was supported by the Xunta de Galicia and the Spanish Ministry of Education and Science through project numbers 08MRU002400PR and AGL2008-02823. The participation of S. Garcia-Marco and M. X. Gomez-Rey was supported by post-doctoral CSIC-I3P contracts, whereas that of A. Couto-Vazquez was supported by a pre-doctoral CSIC-I3P contract. The isotopic ratio mass spectrometer was partly financed by the European Regional Development Fund (EU).

\section{References}

Andreu V, Rubio JL, Forteza J, Cerni R (1996) Postfire effects on soil properties and nutrient losses. InternationalJournal ofWildlandFire 6, 53-58. doi:10.1071/WF9960053 Baird M, Zabowski D, Everett RL

(1999) Wildfire effects on carbon and nitrogen in inland coniferous forests. Plant and Soil 209, 233-243. doi:10.1023/A:1004602408717 Bautista S, Robichaud PR, Blade C

(2009) Post-fire mulching. In 'Fire

Effects on Soils and Restoration Strategies'. (Ed. A Cerda, PR Robichaud) pp. 353-372. (Science Publishers: Enfield, NH) Beyers JL (2004)

Postfire seeding for erosion control: effectiveness and impacts on native plant communities. Conservation Biology 18 ,

947-956. doi: 10.1111/J. 1523- 1739.2004.00523.X Birot Y (Ed.)

(2009) Living with wildfires: what science can tell us. European Forest Institute, Discussion Paper 15. (Joensuu, Finland)

Busse MD (1994) Downed bole-wood decomposition in lodgepole pine forests of central Oregon. Soil Science Society of America Journal 58, 221-227. doi:10.2136/SSSAJ1994.03615995005800010033X Carreira

JA, Niell FX (1995) Mobilization of nutrients by fire in a semiarid gorse-scrubland ecosystem of Southern Spain. Arid Soil Research and Rehabilitation 9, 73-89. doi: 10.1080/15324989509385875 Cerda A,

Lasanta T (2005) Long-term erosional responses after fire in the Central Spanish Pyrenees - 1. Water and sediment yield. Catena 60, 59-80. doi:10.1016/J.CATENA.2004.09.006 Certini G (2005) Effects

of fire on properties of forest soils: a review.

Oecologia 143, 1-10. doi:10.1007/S00442-004-1788-8 de Koff JP,

Graham RC, Hubbert KR, Wohlgemuth PM (2006) Prefire and postfire erosion of soil nutrients within a chaparral watershed. Soil Science 171, 915-928. doi:10.1097/01.SS.0000235231.02063.C2

Debano LF, Conrad CE (1978) The effect of fire on nutrients in a chaparral ecosystem. Ecology 59, 489^97. doi: 10.2307/1936579 DeBano LF, Neary D, Ffolliott PF (Eds) (1998) 'Fires effects on ecosystems'. (Wiley: New York)
Diaz-Fierros F, Benito Rueda E, Perez Moreira R (1987) Evaluation of the U. S.L.E. for the prediction of erosion in burnt forest areas in Galici (NW Spain). Catena 14, 189-199. doi:10.1016/S0341-8162(87)80017-6

Diaz-RavinaM, Martin A, BarreiroA, LombaoA, IglesiasL, Diaz-Fierros F, Carballas T (2012) Mulching and seeding treatments for post-fire soil stabilisation in NW Spain: short-term effects and effectiveness Geoderma 191, 31-39. doi:10.1016/J.GEODERMA.2012.01.003

Emmerich WE (1999) Nutrient dynamics of rangeland burns in Southeastern Arizona. Journal of Range Management 52, 606-614. doi: 10.2307/ 4003630

Feller MC (1988) Relationships between fuel properties and slashburning-induced nutrient losses. Forest Science 34, 998-1015.

Fernandez C, Vega JA, Jimenez E, Fonturbel T (2011) Effectiveness of three post-fire treatments at reducing soil erosion in Galicia (NW Spain). International Journal of Wildland Fire 20, 104-114. doi: 10.1071/ WF09010

Fernandez C, Vega JA, Jimenez E, Vieira DCS, Merino A, Ferreiro A, Fonturbel T (2012) Seeding and mulching+seeding effects on post-fire runoff, soil erosion and species diversity in Galicia (NW Spain). Land Degradation \& Development 23, 150-156. doi: 10.1002/LDR.1064

Fonturbel MT, Barreiro A, Vega JA, Martin A, Jimenez E, Carballas T, Fernandez C, Diaz-Ravina M (2012) Effects of an experimental fire and post-fire stabilization treatments on soil microbial communities. Geoderma 191, 51-60. doi:10.1016/J.GEODERMA.2012.01.037

Gabet EJ, Fierer N, Chadwick OA (2005) Prediction of sediment-bound nutrient delivery from semi-arid California watersheds. Journal of Geophysical Research - Biogeosciences 110, G02001. doi:10.1029/ 2005JG000032

Gimeno-Garcia E, Andreu V, Rubio JL (2000) Changes in organic matter, nitrogen, phosphorus and cations in soil as a result of fire and water erosion in a Mediterranean landscape. European Journal of Soil Science 51, 201-210. doi:10.1046/J.1365-2389.2000.00310.X

Grier CC (1975) Wildfire effects on nutrient distribution and leaching in a coniferous ecosystem. Canadian Journal of Forestry 5, 599-607. doi:10.1139/X75-087

Groen AH, Woods SW (2008) Effectiveness of aerial seeding and straw mulch for reducing post-wildfire erosion, north-western Montana, USA. International Journal of Wildland Fire 17, 559-571. doi:10.1071/ WF07062

Helvey JD, Tiedemann AR, Anderson TD (1985) Plant nutrient losses by soil-erosion and mass movement after wildfire. Journal of Soil and Water Conservation 40, 168-173.

Khan SA, Mulvaney RL, Mulvaney CS (1997) Accelerated diffusion methods for inorganic-nitrogen analysis of soil extracts and water. Soil Science Society of America Journal 61, 936-942. doi: 10.2136/ SSSAJ1997.03615995006100030032X

Khanna PK, Raison RJ, Falkiner RA (1994) Chemical properties of ash derived from eucalyptus litter and its effects on forest soils. Forest Ecology and Management 66, 107-125. doi:10.1016/0378-1127(94) 90151-1

Kruse R, Bend E, Bierzychudek P (2004) Native plant regeneration and introduction of non-natives following post-fire rehabilitation with straw mulch and barley seeding. Forest Ecology and Management 196, 299-310. doi:10.1016/J.FORECO.2004.03.022

Lane PNJ, Sheridan GJ, Noske PJ, Sherwin CB (2008) Phosphorus and nitrogen exports from SE Australian forests following wildfire. Journal of Hydrology 361, 186-198. doi:10.1016/J.JHYDROL.2008.07.041

MartinDA, Moody JA (2001) Comparison of soil infiltration rates in burned and unburned mountainous watersheds. Hydrological Processes 15, 2893-2903. doi:10.1002/HYP.380

Means JE, MacMillian PC, Cromack JK (1992) Biomass and nutrient content of Douglas-fir logs and other detrital pools in an old-growth forest, Oregon USA. Canadian Journal of Forest Research 22, 1536-1546. doi: 10.1139/X92-204 
Moody JA, Martin DA (2009) Synthesis of sediment yields after wildland fire in different rainfall regimes in the western United States. Interna-tionalJournal of Wildland Fire 18(1), 96-115. doi:10.1071/WF07162

Peppin D, Fule PZ, Sieg CH, Beyers JL, Hunter ME (2010) Post-wildfíre seeding in forests of the western United States: an evidence-based review. Forest Ecology and Management 260(5), 573-586. doi:10.1016/J.FORECO.2010.06.004

Pinaya I, Soto B, Arias M, Díaz-Fierros F (2000) Revegetation of burnt áreas: relative effectiveness of native and commercial seed mixtures. LandDegradation \& Development 11,93-98. doi:10.1002/(SICI)1099-145X(200001/02)11:1<93:AID-LDR380>3.0. $\mathrm{CO} ; 2-\mathrm{U}$

Robichaud PR (2009) Post-fire stabilization and rehabilitation. In 'Fire effects on soils and restoration strategies.' (Ed. A Cerda, PR Robichaud) pp. 299-320. (Science Publishers: Enfield, NH)

Robichaud PR, Brown RE (1999) What happened after the smoke cleared: Onsite erosión rates after a wildfire in Eastern Oregon. In 'Wildland Hydrology Conference. ' (Eds DS Olsen, JP Potyondy) pp. A19-A26. (American Water Resources Association: Bozeman, MT)

Robichaud PR, Brown RE (2002) Silt fences: an economical technique for measuring hillslope soil erosión. USDA Forest Service, Rocky Mountain Research Station, General Technical Report RMRS-GTR-94. (Fort Collins, CO)

Robichaud PR, Beyers JL, Neary DG (2000) Evaluating the effectiveness of postfire rehabilitation treatments. USDA Forest Service, Rocky Mountain Research Station, General Technical Report RMRS-GTR-63. (Fort Collins, CO)

Robichaud PR, Lillybridge TR, Wagenbrenner JW (2006) Effects of postfire seeding and fertilizing on hillslope erosión in north-central Washington, USA. Catena 67, 56-67. doi:10.1016/J.CATENA.2006. 03.001

Robichaud PR, Ashmun LE, Sims BD (2010) Post-fire treatment effectiveness for hillslope stabilization. USDA Forest Service, Rocky Mountain Research Station, General Technical Report RMRS-GTR-240. (Fort Collins, CO)

Saá A, Trasar-Cepeda MC, Soto B, Gil-Sotres F, Diaz-Fierros F (1994) Forms of phosphorus in sediments eroded from burnt soils. Journal of Environmental Quality 23, 739-746. doi:10.2134/JEQ1994. 00472425002300040018X

Shakesby RA, Coelho COA, Ferreira AJD, Walsh RPD (2002) Ground-level changes after wildfire and ploughing in eucalyptus and pine forests, Portugal: implications for soil microtopographical development and soil longevity. Land Degradation \& Development 13,111-127. doi: 10.1002/ LDR.487
Smith HG, Sheridan GJ, Lañe PNJ, Nyman P, Haydon S (2011) Wildfire effects on water quality in forest catchments: a review with implications for water supply. Journal of Hydrology 396, 170-192. doi: 10.1016/ J.JHYDROL.2010.10.043

Soto B, Basanta R, Diaz-Fierros F (1997) Effects of burning on nutrient balance in an área of gorse (Ulex europaeus L.) scrub. The Science of the Total Environment 204, 271-281. doi:10.1016/S0048-9697(97)00185-X

Spigel KM, Robichaud PR (2007) First-year post-fire erosión rates in Bitterroot National Forest, Montana. Hydrological Processes 21, 998-1005. doi:10.1002/HYP.6295

Stephens SL, Meixner T, Poth M, McGurk B, Payne D (2004) Prescribed fire, soils, and stream water chemistry in a watershed in the Lake Tahoe Basin, California. International Journal of Wildland Fire 13, 27-35. doi:10.1071/WF03002

Thomas AD, Walsh RPD, Shakesby RA (1999) Nutrient losses in eroded sediment after fire in eucalyptus and pine forests in the wet Medi-terranean environment of northern Portugal. Catena 36, 283-302. doi:10.1016/S0341-8162(99)00051-X

Thomas AD, Walsh RPD, Shakesby RA (2000) Post-fire forestry manage-ment and nutrient losses in eucalyptus and pine plantations, northern Portugal. Land Degradation \& Development 11, 257-271. doi: $10.1002 /$ 1099-145X(200005/06)11:3<257::AID-LDR383>3.0.CO;2-C

Vega JA, Fernandez C, Fonturbel T (2005) Throughfall, runoff and soil erosión after prescribed burning in gorse shrubland in Galicia (NW Spain). Land Degradation \& Development 16, 37-51. doi:10.1002/ LDR.643

Vega JA, Fernández C, Fonturbel T, Jiménez E, Díaz-Raviña M, Martín A, Carballas T (2010) Comparación de tratamientos de mulching y siembra de herbáceas para control de erosión tras un fuego experimental en matorral en Galicia. In 'International workshop Fuegored 2010. Research and Post-fire Management: Soil Protection and Rehabilitation Techniques for Burnt Forest Ecosystems'. pp. 297-300 (FUEGORED: Santiago de Compostela, Spain). Available at http://www.iiag.csic.es/ fuegored/libro.pdf [Verified 18 December 2012]

Wagenbrenner JW, MacDonald LH, Rough D (2006) Effectiveness of three post-fire rehabilitation treatments in the Colorado Front Range. Hydrological Processes 20, 2989-3006. doi:10.1002/HYP.6146 